University of Nebraska - Lincoln

DigitalCommons@University of Nebraska - Lincoln

Publications from the Center for Applied Rural Innovation (CARI)

CARI: Center for Applied Rural Innovation

July 1999

PREDICTING COMMUNITY SATISFACTION AMONG RURAL RESIDENTS: AN INTEGRATIVE MODEL

\author{
Rebecca Filkins \\ University of Nebraska-Lincoln, rvogt2@unl.edu \\ John C. Allen \\ University of Nebraska-Lincoln, jallen1@unl.edu \\ Sam Cordes \\ University of Nebraska-Lincoln, scordes1@unl.edu
}

Follow this and additional works at: https://digitalcommons.unl.edu/caripubs

Part of the Rural Sociology Commons

Filkins, Rebecca; Allen, John C.; and Cordes, Sam, "PREDICTING COMMUNITY SATISFACTION AMONG RURAL RESIDENTS: AN INTEGRATIVE MODEL" (1999). Publications from the Center for Applied Rural Innovation (CARI). 34.

https://digitalcommons.unl.edu/caripubs/34

This Article is brought to you for free and open access by the CARI: Center for Applied Rural Innovation at DigitalCommons@University of Nebraska - Lincoln. It has been accepted for inclusion in Publications from the Center for Applied Rural Innovation (CARI) by an authorized administrator of DigitalCommons@University of Nebraska Lincoln. 


\title{
PREDICTING COMMUNITY SATISFACTION AMONG RURAL RESIDENTS: AN INTEGRATIVE MODEL ${ }^{1}$
}

\author{
Rebecca Filkins, John C. Allen, and Sam Cordes \\ Center for Rural Community Revitalization and Development, University of Nebraska-Lincoln, \\ Lincoln, Nebraska 68583 \\ Department of Agricultural Economics, University of Nebraska-Lincoln, \\ Lincoln, Nebraska 68583
}

\begin{abstract}
Community satisfaction has often been linked to the level of satisfaction with a community's infrastructure, job opportunities and social support networks. Yet, most empirical analyses of community satisfaction have focused on only one aspect of the available theory to predict community satisfaction. In this paper, we integrate multiple models to analyze community satisfaction of almost 4,000 rural Nebraskans. The integrated model indicates that social ties may have a greater role in predicting community satisfaction than had been previously thought.
\end{abstract}

\section{Introduction}

Previous research has suggested that dissatisfaction with one's community may influence the desire to relocate to another community (Zuiches, 1981). Often, for people who are dissatisfied with their current community, the level of satisfaction with the community and its attributes influence a decision to look for other residential locations and often to move to another community. Studies in the late 1970's and early 80's have shown the connection between community satisfaction and residential choice (Heaton et al., 1979; Fredrickson et al., 1980).

Given the apparent and not surprising relationship between "community satisfaction" and residential location decisions, the importance of understanding what affects "community satisfaction" becomes of obvious importance. This is especially true in many rural areas where considerable concern exists over populations that are declining or are experiencing stagnant growth. Nowhere in rural America is this of greater concern than in the Great Plains region. In

\footnotetext{
${ }^{1}$ Journal Series No. 12451, Agricultural Research Division, University of Nebraska, Lincoln, NE.
} 
nearly two-thirds of the region's 478 counties, population peaked prior to 1950 (Rowley, 1998).

Over 40 percent of the counties have seen continuous population decline over the last 40 years and nonmetro counties in the region lost nearly 223,000 residents. Apart from concern over population decline, there is another important reason for wanting to have a better understanding of what factors influence "community satisfaction." Community development practitioners, community leaders, and other local stakeholders see "community cohesion", "a strong sense of community" and similar concepts as having both intrinsic and instrumental value associated with their work and responsibilities.

The main purpose of this paper is to gain an improved understanding of the variables and factors that influence or help to explain levels of "community satisfaction." This is an especially important and fruitful area for additional research in that previous research has typically looked at only one explanatory concept or "domain", e.g., community services or employment opportunities. What is needed is a conceptual framework that includes and integrates such concepts as social ties, economic/employment considerations, and other community attributes such as community services into a more complete explanatory model. This heuristic purpose is another function of this paper - in addition to the other goal of providing insights to policymakers and community leaders and practitioners.

\section{Previous research in community satisfaction}

Previous models in community satisfaction have included many different categories of variables, but no model has yet incorporated all of them simultaneously. Kasarda and Janowitz (1974) developed the systemic model that predicts community attachment using length of residence and a 
person's social position and life-cycle stage as key variables influencing friendship and kinship bonds in the community. In this model, "the local community is viewed as a complex system of friendship and kinship networks and formal and informal associational ties rooted in family life and on-going socialization processes." (Ibid., 1974:329) Additions to this model (Goudy, 1990; Sampson, 1988; and Stinner et al., 1990) have still not incorporated variables depicting different aspects of community life such as satisfaction with community services. The community field theory argues that the community is an interactional structure through which residents fulfill their needs and interests (Wilkinson, 1991). Therefore, all aspects of the community (such as local governmental activities, shopping opportunities, employment opportunities and social interactions) need to be examined to determine how they impact residents' satisfaction with the community.

Respondents' evaluations of community services have been hypothesized to be important determinants of their satisfaction with their community. However, in past studies these evaluations have explained little variance in community satisfaction ratings. A nationwide study by Campbell, Converse and Rodgers (1976) found that ratings of nine community attributes such as schools, climate, streets and roads, parks and playgrounds, and police protection explained only 19 percent of the variance in satisfaction with the community. When personal characteristics were added to the analysis, explained variance only increased to 21 percent.

Goudy (1977) found that social dimensions were of greater importance in determining community satisfaction than previous studies had indicated. The community social dimension scale used in this study consisted of the following items: primary group relationships, community participation, commitment, viability, heterogeneity, power distribution, and community pride. 
This scale accounted for 22 percent of the variance in community attachment, 35 percent of the rating of the community as a place to live and 36 percent in the community evaluation scale. This was considerably greater than the variance explained by evaluations of four local government services (ranging from 0.1 percent to 1.1 percent). The services evaluated were utilities, fire protection, street lighting and maintenance, and waste disposal and sewage system. Local social ties were also included in the analysis. Three questions asked about ties to friends, relatives and general residents of the community. These variables explained from 4.8 percent to 17.8 percent of the total variance in community satisfaction, having the greatest impact on the community attachment variable. When personal characteristics were added, they accounted for very little additional variance. Goudy (1977:380) concluded that “...residents find most satisfying those communities in which they think they have strong primary group relationships, where local people participate and take pride in civic affairs, where decision making is shared, where residents are heterogeneous, and where people are committed to the community and its upkeep."

Brown (1993) argues, however, that these previous studies of community satisfaction and attachment lacked the inclusion of personal economic attitudes and behaviors. Brown argues that these variables are theoretically justified. Improvements in transportation and communication have permitted the separation of residence and place of employment (Castle, 1991; Aldrich et al., 1997). These improvements also allow residents more choices in terms of recreation, goods and services, and participation, which could diminish their attachment to their local community (Goudy and Ryan, 1982; Pinkerton et al., 1995). Therefore, Brown argues that residents can be viewed as "consumers in a larger social/economic context first and residents of a particular community second" (1993:387). Thus, he states a positive experience of community would be 
associated with a high quality of life, which is based on having an adequate income permitting purchases of goods and services. Brown hypothesized that adequate employment and income should be important factors in determining overall satisfaction with a community. The four economic behavior and attitude variables included in his analysis were town of primary employment, satisfaction with employment, satisfaction with income, and outshopping versus inshopping, in addition to the traditional systemic model indicators (length of residence, age, home ownership, density of acquaintanceship and organizational involvement and membership).

Brown did find that the economic indicators explained an additional 12 percent of variance in his community satisfaction index above that explained by the systemic model variables. Satisfaction with employment was the economic variable that was most important in determining community satisfaction and attachment. Location of employment affected some of the variables, while the other two economic variables (satisfaction with income and outshopping versus inshopping) did not significantly influence community satisfaction or attachment.

This is an important finding, but other social variables that were found to be important determinants of community satisfaction (Goudy, 1977) were left out of the analysis, as well as

evaluations of local services in the community. A model that contains all of these variables would determine the relative importance of each in influencing community satisfaction. Drawing on the community field theory, such a model is constructed in this paper.

\section{Methods}

\section{Sample and respondent profile}

The data used in this analysis were collected from the 1997 Nebraska Rural Poll, an annual self-administered questionnaire sent to a random sample of residents living in non-metropolitan 
counties in Nebraska during April of 1997. The respondents were asked questions about their individual well-being, their community, their opinions regarding various government policy issues, and their general demographic characteristics. The random sample included 7,000 nonmetropolitan residents. This report is based on 3,264 completed questionnaires received out of approximately 6,400 deliverable surveys (response rate $=51$ percent). The total design method was used in developing and administering the survey (Dillman, 1978).

The average respondent was 53 years of age and had lived in their community for 31 years. Seventy-two percent were male. Sixty percent of the respondents reported their approximate household income from all sources, before taxes, for 1996 was below \$39,999. Twenty-five percent reported incomes over $\$ 50,000$. Ninety percent had attained at least a high school diploma.

\section{Model and Variables}

As noted earlier, the main purpose or objective of this paper is to gain an improved understanding of the variables and factors that influence or help to explain levels of community satisfaction. Hence, community satisfaction is the dependent variable. There is no singular agreed-upon measure of community satisfaction ${ }^{2}$. In this study, a global community satisfaction measure was

\footnotetext{
${ }^{2}$ Brown (1993) used three separate indicators of community satisfaction. These indicators included evaluations of community rating (comparing it to the respondent's ideal community), community desirability (asking if the community has become more or less desirable as a place to live over the past five years), and life in the community (how satisfied they are with living in their community). Goudy (1977) constructed three scales to measure community satisfaction. The first included three items that measured general satisfaction with the community of residence (satisfaction with the community as a place to live, satisfaction with the quality of life in the community, and agreeing that the community is an ideal place to live). The second scale consisted of three indicators of personal sentiment toward the community (feeling "at home" in the community, interest in what goes on in the community, and feelings about having to move from the community). The final scale was formed from eight items of respondents' perceptions of several aspects of the local community (the community's future, the
} 
used. Respondents were asked to indicate how satisfied they were with their community using a five-point scale, where 1 indicated "very dissatisfied" and 5 denoted "very satisfied".

Based on previous work of others, the independent or explanatory variables used in the study fell into four categories: personal social/spiritual satisfaction, personal economic satisfaction, personal characteristics of the respondent, and general community attributes. In the same way that there is no singular measure of community satisfaction, neither is there a singular accepted measure for the four categories of explanatory variables used in this analysis. Indeed, many specific independent variables could logically be included within each category -- either as proxy or "direct" measures. Our choice of specific variables was guided in part by data availability and in part by the experience and findings of other researchers.

The first explanatory category, personal social/spiritual satisfaction, has been an important dimension of the systemic model of community attachment. This model indicates that local friendship and kinship ties foster strong community sentiments (Kasarda and Janowitz, 1974). The number of friends and relatives living nearby were shown to influence community sentiments in several studies (Kasarda and Janowitz, 1974; Goudy, 1990; Brown, 1993). Instead of using these traditional measures, the respondent's satisfaction with these items was included in this analysis. The scale was operationalized similar to the community satisfaction scale. Specifically, the respondents were asked how satisfied they were with their family, friends, and

community leaders, the innovativeness of the community residents, residents' opinions toward the community, good relations among residents, residents' willingness to work together for the community, general sentiments toward the community and the change occurring in the community over the past 5 years). Goudy's second scale replicated items used by Kasarda and Janowitz (1974). 
religion/spirituality using the same five-point scale described above ${ }^{3}$. These three scales were combined to create the personal social/spiritual satisfaction variable.

The second category of variables, personal economic satisfaction, was included based on the findings of Brown (1993). As stated earlier, his economic indicators explained an additional 12 percent of variance in his community satisfaction index above that explained by the traditional systemic model variables. In particular, satisfaction with employment was found to be an important determinant of community satisfaction. One aspect of the personal economic satisfaction category is referred to in our analysis as a personal employment satisfaction scale. In this case, respondents were asked to indicate their satisfaction with three factors: their job satisfaction, their job security, and their job opportunities. In addition to the personal employment satisfaction scale, two other variables were included in the economic satisfaction category of variables. One of these reflected the respondent's satisfaction with their current income level and the other their satisfaction relative to their future financial security (during retirement).

The third category of variables included in the analysis is the personal characteristics of the respondents: age, gender, household income, education and years lived in their community. Education and household income were coded so that higher numbers represented higher levels on these variables. Gender was coded 0 for male and 1 for female. Length of residence, social class,

3 Respondents were given the option of selecting a box denoting "does not apply" for all of the personal satisfaction questions. The respondents checking these boxes are not included in that particular variable. Since cases with missing values were excluded pairwise in the regression analyses, these respondents were not necessarily excluded altogether from the analyses. However, it is important to note that certain types of respondents may be undercounted in the analysis, for example those without jobs who were not included in the employment satisfaction variable. 
and life-cycle stage have all been found to influence community sentiments (Kasarda and Janowitz, 1974; Goudy, 1977; Goudy, 1990; and Stinner et. al, 1990;)

The final category of variables, general community attributes, has been included in many community satisfaction studies (Campbell et. al, 1976; Goudy, 1977; Sofranko and Fliegel, 1984; and Christenson and Taylor, 1983). Ratings of nine community attributes such as schools, streets and roads, and police protection explained 19 percent of the variance in the study by Campbell, Converse and Rodgers (1976). Goudy (1977) did not find a strong relationship between evaluations of four local government services and community satisfaction, but did find that the social dimensions of a community were important. This analysis includes nine specific community attribute variables. Six of these variables were generated by applying factor analysis, i.e., principal factor extraction with varimax rotation. Factor analysis enables one to simplify a number of measures into groups which are highly correlated and are presumed to reflect common characteristics (Child, 1970).

The first factor -- social attributes -- includes three aspects of the community, as assessed by the respondents. Specifically, respondents were asked if they would describe their communities as friendly or unfriendly, trusting or distrusting, and supportive or hostile. For each of these three dimensions, respondents were asked to "rate" their community using a seven-point scale between each pair of contrasting views. Each scale was coded so that 7 indicated friendly, trusting and supportive. The Cronbach alpha value for this factor was .90 , the highest of the six factors created.

An additional five variables were generated using factor analysis and were based upon a question in which the respondents indicated how satisfied they were with 24 different services and 
amenities (taking into consideration availability, cost and quality). A five-point scale was used by the respondents to rate the services and amenities, with 1 being very dissatisfied and 5 being very satisfied. One factor includes evaluations of four human services: head start programs, day care services, senior centers and nursing home care. Another factor consists of evaluations of four transportation services: air service, bus service, rail service and taxi service. The next factor is composed of evaluations of two levels of local government, i.e., county and city/village government. Another factor is made up of three environmental services: sewage disposal, water disposal and solid waste disposal. Evaluations of three consumer services (retail shopping, restaurants, and entertainment) make up the final factor. Table 1 includes the question wordings for each item included in the six factors used in the analysis along with Cronbach's alpha values for each factor.

\section{(Table 1 about here)}

Although evaluations of education ( $\mathrm{K}-12)$ and basic medical care services did not load on any of the above factors, they were included in the analysis based on previous findings from other studies ${ }^{4}$. Campbell et al. (1976) found the evaluation of public schools was most strongly related to community satisfaction of all the community attributes used in their analysis. Also, Sofranko and Fliegel (1984) found the quality of schools was significant in explaining a global community satisfaction variable. With regard to including basic medical care, Christenson and Taylor (1983) found moderate correlations between evaluations of ambulance service and hospitals and clinics and community satisfaction.

${ }^{4}$ A value of 0.6 was used to determine which factor loadings were included in each grouping. Seven of the 24 services/amenities (in addition to education and medical care) did not meet the 6 cut-off for factor loadings: housing, streets and highways, law enforcement, parks and recreation, library services, and mental health services. 
The final community attribute measured was the population of their community. Six answer categories were provided: less than 100; 100 - 499; 500 - 999; 1,000 - 4,999; 5,000 10,000; and over 10,000. These answer categories were coded so that $1=$ less than 100 and $6=$ over 10,000 .

The statistical relationship among the 18 independent variables and between the dependent variable and each of the 18 independent variables was examined. Not too surprisingly, there are some instances of fairly strong correlation among the independent variables, e.g., age and number of years lived in the community ${ }^{5}$. Additionally, there is a pattern of modest correlation among some of the nine specific variables that constitute the general community attribute category.

\section{Results}

Regression analysis was used to gain a more thorough and precise view of the importance of each of the independent variables in helping to explain the variation in the community satisfaction scale $^{6}$. A separate regression analysis was conducted for each of the four categories of variables (Models 1, 2, 3, and 4 in Table 2), as well as a single multiple regression analysis that included all of these variables simultaneously (Model 5).

(Table 2 about here)

${ }^{5}$ A general rule of thumb to use when detecting serious collinearity is correlations in excess of 0.8 (Gujarati, 1992). None of the correlations in this analysis reached that level. In addition, the tolerance and variance inflation factors for each variable were examined. The lowest tolerance value was 0.48 , although the majority of the variables had tolerances of at least 0.7 . The highest variance inflation factor was 2.06 , while the majority of the variables had values of 1.4 or less. None of these statistics indicated multicollinearity.

${ }^{6}$ OLS regression was chosen for these analyses since the goal was to determine the relative importance of each variable in explaining community satisfaction after all the variable groups were included. Previous research had already determined each group of variables to be important predictors of community satisfaction. Therefore, an OLS regression including all of the variables simultaneously was chosen for this endeavor. 
Personal social/spiritual satisfaction is an important factor in determining community satisfaction. The social/spiritual scale explained 18 percent of the variance in community satisfaction ratings. The more satisfied a resident is with their social/spiritual areas of their life, the higher their community satisfaction score.

The personal economic satisfaction variables also influenced community satisfaction. Together these three variables accounted for 15.8 percent of the variance in the ratings. The personal employment satisfaction scale had the most influence of these three variables.

Model 3 included the personal characteristics category of variables. Although four of the five variables in this category were statistically significant, they accounted for very little of the variance in the community satisfaction scale.

The general community attributes accounted for 30.9 percent of the variance in the community satisfaction scale. The community social attributes influenced this scale more than any of the other community attribute variables. Other statistically significant variables were local government services, environmental services, consumer services, education and basic medical care.

When all these categories of variables are entered into the equation simultaneously, the two social variables (community social attributes and the personal social/spiritual satisfaction scale) appear to influence the community satisfaction scale more than the others (based on the strength of the beta scores). Specifically, when respondents are satisfied with the social/spiritual areas of their life and when they view their community as friendly, trusting and supportive, the more positively they feel about their community as measured by the community satisfaction scale.

Satisfaction with several community services also influences satisfaction with the 
community. Satisfaction with local government services, consumer services, education (K - 12), and human services affect satisfaction levels with the overall community. However, as noted above, the social attributes of the community influence community satisfaction more than these specific services. Moreover, the negative sign on the human services variable was contrary to what was expected, i.e., as satisfaction with human services increased, scores on the community satisfaction scale decreased. It is not easy to rationalize this unexpected finding. It may be that most of the respondents had not had much direct experience with this group of services which would raise questions about (a) their evaluation of "satisfaction" and/or (b) how their evaluation may rate or influence their overall view of community satisfaction.

Satisfaction with employment factors and satisfaction with financial security during retirement also appear to play a role in community satisfaction. These were the two personal economic satisfaction variables that were statistically significant in this analysis. Three personal characteristic variables had a statistically significant relationship to the community satisfaction scale. These were age, education and gender. As a person ages, the more satisfied they become with their community, but as education increases the less satisfied respondents are with their community. Education, like human services, was not statistically significant until it was incorporated into the full model. However, the negative sign on education is easier to rationalize than in the case of the human services variable. Specifically, it may be that expectations of those with higher educational levels are relatively high, causing them to be more critical of and less satisfied with various dimensions of their community. Females were more likely than males to have higher community satisfaction scores. Variables that did not show a statistically significant relationship to the community satisfaction scale were: current income level satisfaction; years 
lived in community; household income; and satisfaction with transportation services, environmental services and basic medical care; and community size.

\section{Discussion}

The social dimensions of a community and satisfaction with social/spiritual factors appear to be important determinants of community satisfaction. Most satisfying to the respondents were communities they considered to be friendly, trusting and supportive. Also, the more satisfied they were with social/spiritual factors, the more satisfied they were with their community. This finding is consistent with Goudy's conclusion that higher levels of community satisfaction are reported when the community is held in high esteem on its social dimensions (1977:380). However, one must be cautious in interpreting the relationship between community satisfaction and the social/spiritual satisfaction scale. This may reflect that people who are satisfied with the interpersonal dimensions of their life are also generally more satisfied with other aspects of their life (including their communities).

The results of this analysis also support Brown's (1993) findings that satisfaction with employment is an important predictor of community satisfaction. However, when the social attributes of the community (friendliness, trusting nature and supportiveness) were included in the analysis along with a measure of satisfaction with personal employment factors, the social dimensions appeared to be relatively more important (as judged by the strength of the beta scores). Another important finding of this analysis is that certain community services appear to influence community satisfaction more than others. Those that seem to be of particular importance are local government, consumer services, and education. 
While results from this study suggest that employment considerations are important, it is interesting that the two variables of most importance are built upon noneconomic considerations (family, friends, religion/spirituality, and how the community rated in terms of being friendly, trusting and supportive). Therefore, Brown's argument that many rural residents are consumers first and residents of their community second may not necessarily hold true in Nebraska. Rural residents are becoming "less tied to the trade and service functions of specific communities" (O'Brien et al., 1998:116). Residents can reside in smaller communities to experience the quality of life benefits accompanying a rural lifestyle (Ibid., 1998). The increase of choices in services, recreation, and location of employment that have resulted from increased technology and communication does not necessarily diminish attachment to place. People have more choices which means that fewer are forced to either stay in a place or leave. The tie of community becomes a bond among people who share a given place (Wilkinson, 1991). "A complete local society can exist with components that are linked to the outside, and if it does exist, it provides a basis for the local population to engage in community actions" (Wilkinson, 1986:5).

As Goudy concluded in his analysis, "Although it could be argued that accounting for more than 40 percent of the variance in community satisfaction is laudable, more than half the variance remains unexplained." He goes on to state, "Community satisfaction is a concept of such breadth and depth that it encompasses evaluations of local services and social variables but is not fully accounted for by these items." (1977:381) More work is needed to determine how the changing dynamics of rural communities affect satisfaction levels. If indeed communities are increasingly becoming mainly places of residence and no longer provide the majority of a resident's services, recreation and employment opportunities, this is an important consideration 
for community development planning.

Over the years many analysts, policymakers, and practitioners have looked askance at the "touchy-feely" and process-oriented approach to community development. These results suggest such efforts may not be entirely misguided after all. And, it may be easier for the local community to find success in improving the noneconomic domain, including the adequate provisions of local government and educational services, than it is to improve local economic conditions. Moreover, and as was already noted, existing commuting patterns and the future possibility of "telecommuting" may weaken the strength of the linkage between a vibrant local economy and indigenous employment opportunities. In this scenario, efforts to strengthen the local economy may become less important than was the case prior to the development of the telecommuting phenomenon. Ultimately, however, it would seem judicious to recognize the importance of both economic and noneconomic considerations, and to also recognize that it is not necessary for the practitioner and others to have to choose one over the other, i.e., they can be viewed as complimentary NOT competitive domains.

Although based on data from only one state, this paper helps provide a more complete or inclusive framework for understanding and operationalizing "community satisfaction". However, it too, leaves more than one-half of the variance in community satisfaction unexplained.

Obviously, much additional work is needed, and the current environment makes the importance of such studies particularly timely. For example, we need much better insights as to how traditional variables used in community satisfaction studies interact with the variables representing "the consumer economy context". Additionally, we continually need to refine our measures, and give consideration to which specific variables best capture and represent our conceptual frameworks. 
For example, our measures of "personal economic satisfaction" may not adequately reflect the role played by spouses or other adult workers in the household.

Another area that needs to be examined in future research is what impact the new information age will have on rural communities and community satisfaction. To the extent changes in technology allow communities and their residents to interact, shop, and work far beyond the traditional "geographic community", existing paradigms, variables, and measures used in community satisfaction studies may become quickly outmoded. Given such dynamics and the importance of this area to policy, practitioners, and local stakeholders, an extremely rich and rewarding research agenda exists. Hopefully, rural sociologists and other rural social scientists will capitalize on this opportunity. 
Table 1. Items included in each multi-item scale.

\begin{tabular}{|c|c|c|c|}
\hline Items & $\begin{array}{l}\text { Mean } \\
\text { score }\end{array}$ & $\begin{array}{l}\text { Standard } \\
\text { deviation }\end{array}$ & $\begin{array}{c}\text { Cronbach's } \\
\text { alpha }\end{array}$ \\
\hline $\begin{array}{l}\text { Personal social/spiritual satisfaction scale: } \\
\text { Please indicate how satisfied you are with each of the } \\
\text { following items: } \\
\text { Your family } \\
\text { Your friends } \\
\text { Your religion/spirituality }\end{array}$ & 13.02 & 1.99 & 0.73 \\
\hline $\begin{array}{l}\text { Personal employment satisfaction scale: } \\
\text { Your job satisfaction } \\
\text { Your job security } \\
\text { Job opportunities for you }\end{array}$ & 10.38 & 2.94 & 0.80 \\
\hline $\begin{array}{l}\text { Social attributes: } \\
\text { Listed below are several pairs of contrasting views } \\
\text { regarding your community. For each pair please } \\
\text { indicate which one of the two views you most agree } \\
\text { with - the one in the left-hand column or the one in } \\
\text { the right-hand column - by circling the appropriate } \\
\text { number on the line between them. My community is... } \\
\text { Friendly.....Unfriendly } \\
\text { Trusting.....Distrusting } \\
\text { Supportive.....Hostile }\end{array}$ & 15.20 & 4.01 & 0.90 \\
\hline $\begin{array}{l}\text { Human services: } \\
\text { Listed below are public services and community } \\
\text { amenities that many citizens believe are important. } \\
\text { Thinking about availability, cost, quality, and any } \\
\text { other considerations important to you, how satisfied or } \\
\text { dissatisfied are you with each item listed below? } \\
\text { Head start programs } \\
\text { Day care services } \\
\text { Senior centers } \\
\text { Nursing home care }\end{array}$ & 11.37 & 2.73 & 0.74 \\
\hline $\begin{array}{l}\text { Transportation services: } \\
\text { Air service } \\
\text { Bus service } \\
\text { Rail service } \\
\text { Taxi service }\end{array}$ & 10.96 & 3.11 & 0.81 \\
\hline $\begin{array}{l}\text { Local government services: } \\
\text { County government } \\
\text { City/village government }\end{array}$ & 6.32 & 2.11 & 0.80 \\
\hline $\begin{array}{l}\text { Environmental services: } \\
\text { Sewage disposal } \\
\text { Water disposal }\end{array}$ & 11.37 & 2.73 & 0.84 \\
\hline $\begin{array}{l}\text { Solid waste disposal } \\
\text { Consumer services: } \\
\text { Retail shopping } \\
\text { Restaurants } \\
\text { Entertainment }\end{array}$ & 9.42 & 3.12 & 0.77 \\
\hline
\end{tabular}


Table 2. Prediction of community satisfaction by community attributes, personal characteristics, local social ties, and personal economic attitudes

\begin{tabular}{|c|c|c|c|c|c|c|c|c|c|c|}
\hline \multirow[b]{2}{*}{ Predictor Variables } & \multicolumn{2}{|c|}{ Model 1} & \multicolumn{2}{|c|}{ Model 2} & \multicolumn{2}{|c|}{ Model 3} & \multicolumn{2}{|c|}{ Model 4} & \multicolumn{2}{|c|}{ Model 5} \\
\hline & $\mathrm{B}$ & Beta & $\overline{\mathrm{B}}$ & Beta & $\mathrm{B}$ & Beta & $\mathrm{B}$ & Beta & $\mathrm{B}$ & Beta \\
\hline \multicolumn{11}{|l|}{ Personal social/spiritual satisfaction: } \\
\hline Personal social/spiritual satisfaction scale & .224 & $.424 * * *$ & & & & & & & .138 & $.261 * * *$ \\
\hline \multicolumn{11}{|l|}{ Personal economic satisfaction: } \\
\hline Personal employment satisfaction scale & & & .103 & $.286 * * *$ & & & & & .056 & $.157 * * *$ \\
\hline Current income level satisfaction & & & .006 & .007 & & & & & -.004 & -.004 \\
\hline $\begin{array}{l}\text { Financial security during retirement } \\
\text { satisfaction }\end{array}$ & & & .142 & $.176^{* * *}$ & & & & & .047 & $.058 *$ \\
\hline \multicolumn{11}{|l|}{ Personal characteristics of respondent: } \\
\hline Age & & & & & .011 & $.189 * * *$ & & & .004 & $.070 * * *$ \\
\hline Years lived in community & & & & & .003 & $.062 * *$ & & & -.001 & -.014 \\
\hline Household income & & & & & .029 & $.054 * *$ & & & -.008 & -.016 \\
\hline Education & & & & & -.011 & -.017 & & & -.026 & $-.039 *$ \\
\hline Gender & & & & & .120 & $.051 * *$ & & & .100 & $.042 *$ \\
\hline \multicolumn{11}{|l|}{ General community attributes: } \\
\hline Social attributes & & & & & & & .080 & $.306 * * *$ & .065 & $.247 * * *$ \\
\hline Human services & & & & & & & -.002 & -.005 & -.017 & $-.046^{*}$ \\
\hline Transportation services & & & & & & & -.011 & -.031 & -.004 & -.012 \\
\hline Local government services & & & & & & & .101 & $.201 * * *$ & .077 & $.154 * * *$ \\
\hline Environmental services & & & & & & & .014 & $.037 *$ & .008 & .021 \\
\hline Consumer services & & & & & & & .046 & $.137 * * *$ & .036 & $.107 * * *$ \\
\hline Education $(\mathrm{K}-12)$ & & & & & & & .080 & $.086 * * *$ & .065 & $.069 * * *$ \\
\hline Basic medical care & & & & & & & .045 & $.048 *$ & .024 & .026 \\
\hline Community size & & & & & & & -.007 & -.009 & -.006 & -.008 \\
\hline Variance explained & & $18.0 \%$ & & $15.8 \%$ & & $5.7 \%$ & & $30.9 \%$ & & $43.4 \%$ \\
\hline $\mathrm{F}$ & & $657.95 * * *$ & & $137.43 * * *$ & & $33.69 * * *$ & & $132.10 * * *$ & & $93.19 * * *$ \\
\hline Number of observations & & 3009 & & 2208 & & 2812 & & 2672 & & 2208 \\
\hline
\end{tabular}




\section{References}

Aldrich, Lorna, Calvin Beale, and Kathleen Kassel. 1997. "Commuting and the Economic Functions of Small Towns and Places.” Rural Development Perspectives 12 (3): 26-31.

Brown, Ralph B. 1993. "Rural Community Satisfaction and Attachment in Mass Consumer Society." Rural Sociology 58:387-403.

Campbell, Angus, Philip E. Converse, and Willard L. Rodgers. 1976. The Quality of American Life. New York: Russell Sage.

Castle, Emery N. 1991. “The Benefits of Space and the Cost of Distance” Pp. 41-55 in The Future of Rural America: Anticipating Policies for Constructive Chang, edited by Kenneth E. Pigg. Boulder, CO: Westview Press.

Child, Dennis. 1970. The Essentials of Factor Analysis. New York: Holt, Rinehart and Winston.

Christenson, James A. and Gregory S. Taylor. 1983. "The Socially Constructed and Situational Context for Assessment of Public Services.” Social Science Quarterly 64:264-74.

Dillman, Don A. 1978. Mail And Telephone Surveys: The Total Design Method. New York: Wiley.

Fredrickson, Carl, Tim Heaton, Glenn Fuguitt, and James J. Zuiches. 1980. "Residential Preferences in a Model of Migration Intentions." Population and Environment 3:280-97.

Goudy, Willis J. 1977. "Evaluations of Local Attributes and Community Satisfaction in Small Towns." Rural Sociology 42:371-82.

Goudy, Willis J. 1990. “Community attachment in a rural region.” Rural Sociology 55:178-98.

Goudy, Willis J. and Vernon D. Ryan. 1982. "Changing Communities" Pp. 256-263 in Rural Society in the U.S.: Issues for the 1980s, edited by D.A. Dillman and D. J. Hobbs. Boulder, CO: Westview.

Gujarati, Damodar. 1992. Essentials of Econometrics. St. Louis, MO: McGraw-Hill, Inc.

Heaton, Tim, Carl Fredrickson, Glenn V. Fuguitt, and James J. Zuiches. 1979. "Residential Preferences, Community Satisfaction, and the Intention to Move." Demography 16:565-73.

Kasarda, John D. and Morris Janowitz. 1974. "Community Attachment in Mass Society." American Sociological Review 39:328-39.

O’Brien, David J., Andrew Raedeke, and Edward W. Hassinger. 1998. “The Social Networks of 
Leaders in More or Less Viable Communities Six Years Later: A Research Note.” Rural Sociology 63:109-27.

Pinkerton, James R., Edward W. Hassinger, and David J. O’Brien. 1995. "Inshopping by Residents of Small Communities.” Rural Sociology 60:467-80.

Rowley, Thomas D. 1998. "Sustaining the Great Plains.” Rural Development Perspectives 13:2-6.

Sampson, Robert J. 1988. "Local friendship and community attachment in mass society: a multilevel systemic model.” American Sociological Review 53:766-79.

Sofranko, Andrew J. and Frederick C. Fliegel. 1984. "Dissatisfaction with Satisfaction.” Rural Sociology 49:353-73.

Stinner, William F., Mollie Van Loon, Seh-Woong Chung, and Yongchan Byun. 1990. "Community size, individual social position, and community attachment." Rural Sociology $55: 494-521$.

Wilkinson, Kenneth P. 1986. "In Search of the Community in the Changing Countryside.” Rural Sociology 51:1-17.

Wilkinson, Kenneth P. 1991. The Community in Rural America. New York: Greenwood.

Zuiches, James J. 1981. "Residential Preferences in the United States." Pp. 72-115 in Nonmetropolitan America in Transition, edited by Amos Hawley and Sara M. Mazie. Chapel Hill, NC: University of North Carolina Press. 